\title{
Overcoming beta-agonist tolerance: high dose salbutamol and ipratropium bromide. Two randomised controlled trials Sarah Haney ${ }^{1,2}$ and Robert J Hancox*2,3
}

Address: ${ }^{1}$ Department of Respiratory Medicine, Sunderland Royal Hospital, Sunderland, UK, ${ }^{2}$ Department Respiratory Medicine, Waikato Hospital, Hamilton, New Zealand and ${ }^{3}$ Dunedin Multidisciplinary Health and Development Research Unit, Dunedin School of Medicine, University of Otago, Dunedin, New Zealand

Email: Sarah Haney - sas_haney@yahoo.co.uk; Robert J Hancox* - bob.hancox@otago.ac.nz

* Corresponding author

Published: 6 March 2007

Respiratory Research 2007, 8:19 doi:10.1 186/1465-9921-8-19

This article is available from: http://respiratory-research.com/content/8/1/19

(C) 2007 Haney and Hancox; licensee BioMed Central Ltd.

This is an Open Access article distributed under the terms of the Creative Commons Attribution License (http://creativecommons.org/licenses/by/2.0), which permits unrestricted use, distribution, and reproduction in any medium, provided the original work is properly cited.
Received: 29 June 2006

Accepted: 6 March 2007

\begin{abstract}
Background: Asthmatics treated with long-acting beta-agonists have a reduced bronchodilator response to moderate doses of inhaled short acting beta-agonists during acute bronchoconstriction. It is not known if the response to higher doses of nebulised beta-agonists or other bronchodilators is impaired. We assessed the effect of long-acting beta-agonist treatment on the response to $5 \mathrm{mg}$ nebulised salbutamol and to ipratropium bromide.

Methods: Two double-blind, placebo-controlled, crossover studies of inhaled formoterol $12 \mu \mathrm{g}$ twice daily in patients with asthma.

High-dose salbutamol: 36 hours after the last dose of I week of formoterol or placebo treatment, II subjects inhaled methacholine to produce a $20 \%$ fall in FEV . Salbutamol $5 \mathrm{mg}$ was then administered via nebuliser and the FEV, was monitored for 20 minutes. Ipratropium: 36 hours after the last dose of I week of formoterol or placebo treatment, I I subjects inhaled $4.5 \%$ saline to produce a $20 \%$ fall in $\mathrm{FEV}_{1}$. Salbutamol $200 \mu \mathrm{g}$ or ipratropium bromide $40 \mu \mathrm{g}$ was then inhaled and the FEV , was monitored for 30 minutes. Four study arms compared the response to each bronchodilator after formoterol and placebo. Analyses compared the area under the bronchodilator response curves, adjusting for changes in pre-challenge FEV , dose of provocational agent and $\mathrm{FEV}$, fall during the challenge procedure.
\end{abstract}

Results: The response to nebulised salbutamol was I5\% lower after formoterol therapy compared to placebo ( $95 \%$ confidence 5 to $25 \%, p=0.008)$. The response to ipratropium was unchanged.

Conclusion: Long-acting beta-agonist treatment induces tolerance to the bronchodilator effect of beta-agonists, which is not overcome by higher dose nebulised salbutamol. However, the bronchodilator response to ipratropium bromide is unaffected.

\section{Background}

Patients with asthma who are poorly controlled on inhaled corticosteroids are often prescribed long-acting beta-agonists $[1,2]$. However, most asthmatics continue to need short acting beta-agonists for relief of breakthrough symptoms and for treatment during asthma exacerbations. Despite accumulating evidence that tolerance develops to the bronchodilator effects of beta-agonists, 
the effect of regular long-acting beta-agonists on the response to treatment of exacerbations is rarely considered in treatment guidelines.

Tolerance to the systemic [3] and bronchoprotective [4] effects of beta-agonists is known to occur during regular beta-agonist use. It was previously thought that tolerance to bronchodilation did not occur. However, recent studies have shown that tolerance to bronchodilation is easily demonstrated when tested from a bronchoconstricted state, such as after methacholine or exercise challenge [513]. Patients using regular long-acting beta-agonists may therefore be less responsive to further beta-agonist treatment during acute bronchoconstriction. This is potentially a serious problem for patients who are taking these drugs and experience an exacerbation of asthma.

Studies of bronchodilator tolerance have demonstrated that regular beta-agonist treatment impairs the bronchodilator response to moderate doses of up to $400 \mu \mathrm{g}$ of salbutamol [5-12]. It has been suggested that this tolerance can easily be overcome by administering higher doses of beta-agonists, but this has never been formally examined [14]. Treatment of asthma exacerbations in emergency departments usually includes higher doses of beta-agonists given via a nebuliser, typically up to $5 \mathrm{mg}$ salbutamol $[1,2]$. There have been no randomised controlled trials of the effects of regular long-acting beta-agonists on this emergency treatment.

It is also unknown whether beta-agonist tolerance use affects the airway response to other bronchodilators. The anticholinergic bronchodilator ipratropium bromide is often added to emergency asthma treatment in severe bronchoconstriction and in those who respond poorly to beta-agonist alone $[2,15]$. It is likely that the bronchodilator response to ipratropium is not affected by prior longacting beta-agonist treatment since it acts via a different receptor. However, beta ${ }_{2}$-receptors and muscarinic cholinergic receptors share some intracellular secondary messengers and their signalling pathways may interact $[16,17]$. Hence it is plausible that bronchodilator responsiveness to ipratropium could be affected by beta-agonist tolerance. Moreover, it is possible that beta-agonists have a non-specific effect on airway smooth muscle tone thereby altering the response to other bronchodilators regardless of intracellular signalling pathways $[18,19]$.

Given the role of high dose beta-agonist and ipratropium bromide in the management of asthma exacerbations, it is important to assess their effectiveness in the setting of long-acting beta-agonist treatment. We performed two studies to address the following questions:
Study 1: Does high dose salbutamol overcome the bronchodilator tolerance associated with regular long-acting beta-agonist use?

Study 2: Does beta-agonist bronchodilator tolerance affect the bronchodilator response to ipratropium bromide?

\section{Methods \\ Subjects}

Subjects had physician-diagnosed asthma with a provocative dose to cause a $20 \%$ fall in $\mathrm{FEV}_{1}\left(\mathrm{PD}_{20}\right)$ less than 1.5 mg of methacholine (study 1) or less than $30 \mathrm{ml}$ saline (study 2) at screening (see below). Subjects were not using long-acting beta-agonists prior to the study and had not changed their asthma medications nor had a respiratory tract infection for 6 weeks prior to study entry. The studies were approved by the Waikato Ethics Committee. All subjects provided written informed consent.

\section{Study design}

Both studies were random-order, double-blind, cross-over studies comparing formoterol $12 \mu \mathrm{g}$ twice daily with placebo. Randomisation was by computer-coded bottles of identical capsules for use with the Foradil Aeroliser (Novartis, Auckland, New Zealand). Additional beta-agonists were not allowed throughout the studies. Ipratropium was used for symptom relief.

\section{Study I: High-dose salbutamol}

This was a crossover study with 2 arms. Subjects inhaled formoterol or placebo twice daily for 1 week. Thirty-six hours after the last dose, subjects underwent a methacholine challenge and salbutamol response as described below. Subjects then crossed to the other medication for a repeat sequence of 1 week of treatment, methacholine challenge and salbutamol response.

Methacholine challenge was performed using a modified Yan technique [20]. Subjects inhaled doubling doses of nebulised methacholine until the $\mathrm{FEV}_{1}$ had fallen by $\geq$ $20 \%$. The $\mathrm{PD}_{20}$ methacholine was calculated by linear interpolation of the last two doses. Immediately after completion of the methacholine challenge, subjects were given $5 \mathrm{mg}$ salbutamol via a Sidestream nebuliser and System 22 aerosol mask (Profile, Bognor Regis, UK) powered by oxygen at a rate of $6 \mathrm{~L} /$ minute. $\mathrm{FEV}_{1}$ was measured at 5 , 10,15 and 20 minutes after starting the nebuliser.

\section{Study 2: Ipratropium bromide}

This was a crossover study with four arms. For each arm subjects inhaled formoterol $12 \mu \mathrm{g}$ or placebo twice daily for 1 week. Thirty-six hours after the last dose, subjects underwent a hypertonic saline challenge and bronchodilator response as described below. Subjects then received 
the alternative medication and started the next arm of the study. Two study arms compared the bronchodilator response to salbutamol after formoterol and placebo treatment and the other two arms compared the response to ipratropium bromide after formoterol and placebo.

Hypertonic saline challenge was performed according to the method of the European Respiratory Society [21]. Subjects inhaled $4.5 \%$ saline until the $\mathrm{FEV}_{1}$ fell by $\geq 20 \%$. The $\mathrm{PD}_{20}$ saline was calculated by linear interpolation of the last two doses. Immediately after the challenge, $200 \mu \mathrm{g}$ salbutamol or $40 \mu \mathrm{g}$ ipratropium was given via a metered dose inhaler and large volume spacer. $\mathrm{FEV}_{1}$ was measured $5,10,15,20$ and 30 minutes after the bronchodilator.

\section{Analysis}

The main outcome measurement was the area under the salbutamol or ipratropium response curves (AUC), expressed as a percentage of the fall in $\mathrm{FEV}_{1}$ induced by challenge. Comparisons between treatments were adjusted for baseline $\mathrm{FEV}_{1}$ and dose of provocational agent given using analysis of covariance. A secondary outcome for each study was the final post-bronchodilator $\mathrm{FEV}_{1}$, which was also adjusted for the fall in $\mathrm{FEV}_{1}$ during challenge. Post hoc comparisons between placebo and formoterol treatments were were made using Tukey's exact method. Comparisons of pre-challenge $\mathrm{FEV}_{1}$ and of $\mathrm{PD}_{20}$ were made using paired Student's t-tests. $\mathrm{PD}_{20}$ values were log-transformed for analysis.

Previous studies indicated that a sample size of 12 subjects would detect a $30 \%$ fall in AUC with $80 \%$ power at $\alpha=0.05$ [5].

\section{Results}

\section{Study I: High dose salbutamol}

Eleven subjects were recruited and completed the study. Baseline characteristics of the subjects are shown in table 1. There was no significant effect of order of treatment on AUC, pre-challenge $\mathrm{FEV}_{1}$ or $\mathrm{PD}_{20}$ methacholine. The prechallenge $\mathrm{FEV}_{1}$ and $\mathrm{PD}_{20}$ methacholine were not significantly different between placebo and formoterol arms (table 2).
The salbutamol response, expressed as area under the curve, was $15 \%$ lower in the formoterol period compared to placebo (95\% confidence interval 5 to $25 \%$ ). This was a significant difference when taking the covariates into account $(\mathrm{p}=0.008)$ (table 2, figure 1$)$.

The final $\mathrm{FEV}_{1} 20$ minutes after challenge after $5 \mathrm{mg}$ salbutamol was $2.67 \mathrm{~L}$ in the formoterol arm compared to $2.79 \mathrm{~L}$ after placebo $(95 \% \mathrm{CI}$ for difference 0.06 to $0.19 \mathrm{~L}$; $\mathrm{p}=0.003)$.

\section{Study 2: Ipratropium bromide}

Thirteen subjects were recruited to the study. Two subjects withdrew during the first treatment period, one with uncontrolled asthma and one with a respiratory infection (taking formoterol and placebo respectively). Baseline characteristics are shown in table 1 . There was no effect of order of treatment.

The mean pre-challenge $\mathrm{FEV}_{1}$ and $\mathrm{PD}_{20}$ saline did not change significantly between formoterol and placebo arms. However, one subject experienced a less than $15 \%$ fall in $\mathrm{FEV}_{1}$ with inhalation of saline after taking formoterol. For analytical purposes, the $\mathrm{PD}_{20}$ saline for these challenges has been assumed to be $30 \mathrm{ml}$ (the maximum value available for inhalation). Exclusion of this subject from analysis does not materially alter the results.

The response to ipratropium, expressed as the AUC, was not significantly different between formoterol or placebo treatment arms (table 3, figure 2). The final $\mathrm{FEV}_{1}, 30 \mathrm{~min}$ utes after ipratropium was not significantly different between the formoterol or placebo arms.

The response to salbutamol was reduced in the formoterol arm compared to placebo. The mean difference in the AUC was 26\% (95\% CI 6 to $46 \%$; $=0.02$ ) (table 3, figure 2). The $\mathrm{FEV}_{1} 30$ minutes after salbutamol was also lower in the formoterol arm compared to placebo, $2.74 \mathrm{~L}$ compared to $2.91 \mathrm{~L}$ ( $95 \%$ CI for difference 0.05 to 0.38 ; $\mathrm{p}=$ 0.02 by covariate analysis).

\section{Discussion}

These studies confirm that the response to salbutamol is reduced in subjects taking long-acting beta-agonists. This

Table I: Baseline characteristics of subjects

\begin{tabular}{|c|c|c|}
\hline Study & I. High dose salbutamol & 2. Ipratropium \\
\hline Number of subjects & 11 & 11 \\
\hline Male & 3 & 3 \\
\hline Age (range) & 37 (22 to 62 ) & 34 (19 to 53$)$ \\
\hline Number on inhaled steroids Dose range ( $\mu \mathrm{g}$ )(budesonide equivalent) & $9(200$ to 1200$)$ & $10(200$ to 2000$)$ \\
\hline FEV,$\%$ predicted at screening (range) & $79(61$ to 101$)$ & $86(65$ to 103$)$ \\
\hline
\end{tabular}


Table 2: Results of the high dose salbutamol study (study I)

\begin{tabular}{|c|c|c|}
\hline Treatment & Placebo & Formoterol \\
\hline Pre-challenge $\mathrm{FEV}_{1}(\mathrm{~L})(\mathrm{SD})$ & $2.55(0.75)$ & $2.57(0.72)$ \\
\hline Post challenge $\mathrm{FEV}_{\mathrm{I}}(\mathrm{L})(\mathrm{SD})$ & $1.92(0.59)$ & $2.00(0.51)$ \\
\hline $\mathrm{PD}_{20}$ methacholine $(\mathrm{mg})$ (geometric mean, $95 \% \mathrm{Cl}$ ) & $0.08(0.03,0.22)$ & $0.10(0.04,0.25)$ \\
\hline AUC salbutamol (\%.time) (SD) & $412(140)$ & $339(201)$ \\
\hline Difference: paired t-test $(95 \% \mathrm{Cl})$ & \multicolumn{2}{|c|}{$73(-4,149) p=0.06$} \\
\hline Difference: covariate analysis (placebo-formoterol) (least squares means, $95 \% \mathrm{Cl}$ ) & \multicolumn{2}{|c|}{$63(22,105) p=0.008$} \\
\hline Post-salbutamol FEV at 20 mins (L) (SD) & $2.79(0.86)$ & $2.67(0.84)$ \\
\hline Difference: paired t-test $(95 \% \mathrm{Cl})$ & \multicolumn{2}{|c|}{$0.12(0.03,0.20) \mathrm{p}=0.008$} \\
\hline Difference: covariate analysis (placebo-formoterol) (least squares means, $95 \% \mathrm{Cl}$ ) & \multicolumn{2}{|c|}{$0.12(0.06,0.19) \mathrm{p}=0.003$} \\
\hline
\end{tabular}

reduction in response was evident even when $5 \mathrm{mg}$ salbutamol was given via nebuliser. By contrast, the bronchodilator response to ipratropium was not affected by prior use of formoterol.

It is known that tolerance to bronchodilation occurs following regular formoterol. This has usually been demonstrated by measuring the bronchodilator response to up to $400 \mu \mathrm{g}$ of salbutamol via metered dose inhaler. In terms of bronchodilation, $2.5 \mathrm{mg}$ via a nebuliser is equivalent to $800 \mu \mathrm{g}$ via metered dose inhaler and spacer [22]. We used a $5 \mathrm{mg}$ dose of nebulised salbutamol in this study as this is commonly used in the emergency treatment of asthma. Higher single doses of salbutamol in a nebuliser are not recommended [2]. We found that the response to $5 \mathrm{mg}$ of salbutamol was impaired after 1 week of regular formoterol use, indicating that patients using long-acting betaagonists are likely to respond poorly to first-line treatment of acute severe asthma even if high doses of nebulised beta-agonist are used. Although the differences in the dose-response curves and final $\mathrm{FEV}_{1}$ shown in this study may appear modest, it has been shown that the degree of beta-agonist tolerance increases with the degree of bronchoconstriction [7]. Patients with acute severe asthma will have much more severe bronchoconstriction than the $20 \%$ fall in $\mathrm{FEV}_{1}$ induced in this study $[2,23]$. They are therefore likely to have a much greater impairment in response to beta-agonists. In practice, many patients are given repeated doses of beta-agonists via nebuliser during an acute exacerbation. It was not possible to test the effects of repeated nebulisations using this model owing to the time taken for nebulisation (around 5 minutes) and the effect of spontaneous recovery from methacholineinduced bronchoconstriction.

The findings of the salbutamol study appear to contrast with those of a study which found no difference in the response to emergency department beta-agonist treatment between patients who had been taking long-acting beta-agonists and those who had not [24]. However, this emergency department study did not assess the preceding use of short-acting beta-agonists. Since almost all asthmatics take large doses of beta-agonists before presenting to hospital [25] and tolerance to beta-agonists develops rapidly [11], it is highly likely that the 'control' group had also developed tolerance.

The bronchodilator response to ipratropium bromide was not impaired by prior use of long-acting beta-agonist. This confirms that the effect that we have interpreted as betaagonist tolerance is specific to beta-agonists and unlikely to be due to a non-specific change in airway smooth muscle responsiveness. The intracellular effects of both betaagonists and cholinergic agents are now known to be far more complex than action on single second messenger systems and there are plausible mechanisms of interaction between them $[16,26]$. Muscarinic agonists appear to reduce the potency of beta-agonist bronchodilation, possibly through an effect on adenylyl cyclase [17]. The converse effect of muscarinic antagonists has been more

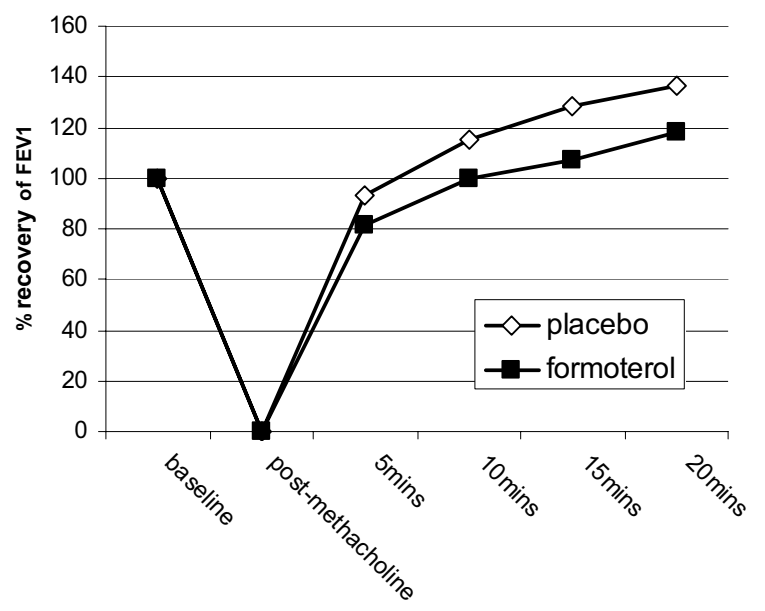

Figure I

Response to high dose salbutamol $(n=I I)$. 
Table 3: Results of the ipratropium study (study 2)

\begin{tabular}{|c|c|c|c|c|}
\hline \multirow{2}{*}{$\begin{array}{l}\text { Bronchodilator } \\
\text { Treatment }\end{array}$} & \multicolumn{2}{|c|}{ Ipratropium } & \multicolumn{2}{|c|}{ Salbutamol } \\
\hline & Placebo & Formoterol & Placebo & Formoterol \\
\hline Pre-challenge $\mathrm{FEV}_{1}(\mathrm{~L})(\mathrm{SD})$ & $2.77(0.50)$ & $2.67(0.4 I)$ & $2.62(0.50)$ & $2.67(0.63)$ \\
\hline Post-challenge $\mathrm{FEV}_{1}(\mathrm{~L})(\mathrm{SD})$ & $2.15(0.38)$ & $2.07(0.37)$ & $2.06(0.4 \mathrm{I})$ & $2.11(0.60)$ \\
\hline $\mathrm{PD}_{20}$ saline $(\mathrm{ml})(95 \% \mathrm{Cl})$ & $11.8(7.4-19)$ & $8.0(4.6-13.8)$ & $8.9(4.9-16.0)$ & $8.6(5.0-14.6)$ \\
\hline AUC \%.time (SD) & $447(215)$ & $401(154)$ & 759 (203) & $557(|3|)$ \\
\hline Difference: paired t-test $(95 \% \mathrm{Cl})$ & \multicolumn{2}{|c|}{$138(-48,138) p=0.303$} & \multicolumn{2}{|c|}{$202(66,339) \mathrm{p}=0.008$} \\
\hline Difference: covariate analysis (placebo-formoterol) (least squares mean, $95 \% \mathrm{Cl}$ ) & \multicolumn{2}{|c|}{$88(-31,207) p=0.126$} & \multicolumn{2}{|c|}{$202(42,362) p=0.019$} \\
\hline $\mathrm{FEV}_{1}$ at 30 mins $(\mathrm{L})(\mathrm{SD})$ & $2.8 I(0.54)$ & $2.67(0.45)$ & $2.91(0.56)$ & $2.74(0.64)$ \\
\hline Difference: paired t-test ( $95 \% \mathrm{Cl})$ & \multicolumn{2}{|c|}{$0.22(0-0.30) p=0.056$} & \multicolumn{2}{|c|}{$0.10(-0.05,0.39) p=0.117$} \\
\hline Difference: covariate analysis (placebo-formoterol) (least squares mean, $95 \% \mathrm{Cl}$ ) & \multicolumn{2}{|c|}{$0.11(-0.06,0.28) p=0.172$} & \multicolumn{2}{|c|}{$0.22(0.05,0.38) p=0.015$} \\
\hline
\end{tabular}

difficult to assess [27]. Acetylcholine in human airways acts via muscarinic receptors to decrease cyclic AMP and reduce intracellular calcium release, thereby causing bronchoconstriction. Ipratropium blocks these actions, thereby reducing smooth muscle tone and causing bronchodilation. Cyclic AMP is also a key second-messenger in the response to beta-receptor activation. Regular exposure to beta-agonists appears to uncouple the beta-receptor from cAMP production [28]. Therefore it seemed possible that beta-agonist tolerance would also have an effect on the response to ipratropium. However, this was not discernible in our study. The addition of ipratropium bromide to beta-agonist treatment in acute severe asthma improves bronchodilation [15], whereas it affords little additional benefit in stable asthma [29]. It is possible that this is because the response to beta-agonist in severe asthma is impaired because of prior beta-agonist treat-

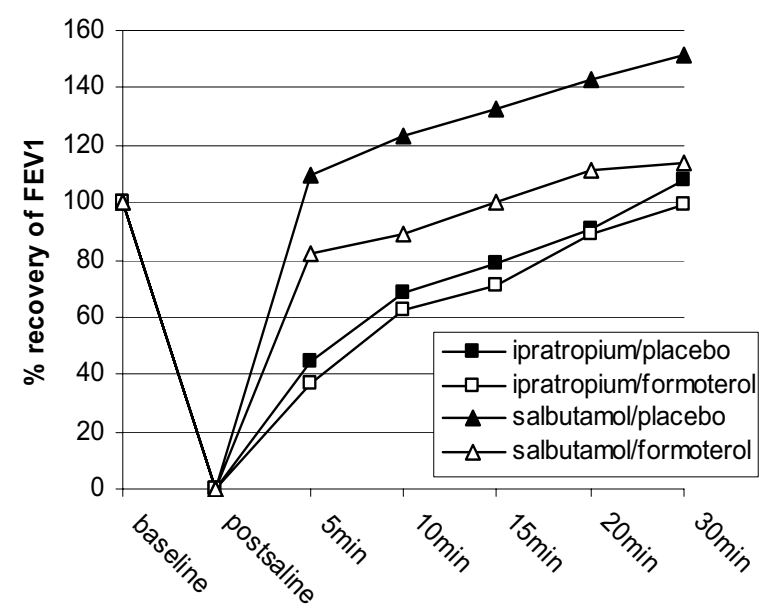

Figure 2

Response to salbutamol and ipratropium bromide $(\mathrm{n}=\mathrm{I} \mathrm{I})$. ment, whereas the response to anticholinergic treatment is maintained. In this study the bronchodilator response to salbutamol was more rapid and greater than to ipratropium bromide, even after tolerance had developed. However, the effect of beta-agonist tolerance increases with increasing levels of bronchoconstriction [7]. In severe asthma the modest response to ipratropium bromide may become more important.

These studies used formoterol as the long-acting beta-agonist. Studies in the emergency department have focussed on patients taking salmeterol [24]. Salmeterol is a partial agonist at the beta-receptor compared to formoterol and theoretically it may be less likely to induce tolerance. Alternatively, salmeterol could act as a partial antagonist to salbutamol and reduce the effects of salbutamol still further. In practice, trials that have compared bronchodilator tolerance using the challenge-rescue model have not found any difference between salmeterol and formoterol $[8,10]$.

We have interpreted the reduction in response to betaagonists as tolerance or tachyphylaxis to the effects of beta-agonists. Downregulation of the beta-receptors both in terms of receptor number and intracellular response to receptor stimulation is a pharmacologically predictable effect of repeated receptor stimulation [28]. An alternative explanation for the reduced response to beta-agonist is that some beta-receptors were still occupied by formoterol molecules at the time of the test and were therefore not available to bind to salbutamol, reducing its effect. We measured the bronchodilator response 36 hours after the last dose of formoterol. This is outside the normal duration of action of formoterol [30] and receptor occupancy should be minimal at this time. The 36-hour withdrawal of formoterol also minimises confounding of the results by large changes in pre-challenge $\mathrm{FEV}_{1}$ and $\mathrm{PD}_{20}$. 
Although one subject showed a bronchoprotective effect at this time, overall there were no significant differences in the pre-challenge $\mathrm{FEV}_{1}$ or $\mathrm{PD}_{20}$ values. However, it is also known that beta-receptors recover rapidly following downregulation [31] and the timing of challenges 36 hours after the last dose of long-acting beta-agonist may mean that the tolerance measured in these trials was actually lower than that experienced by patients who continue take their long-acting beta-agonists twice daily [12].

There are potential limitations to our study design. First, this challenge-rescue model does not accurately reflect all of the pathophysiology of acute asthma, where airway inflammation, oedema and mucus production play important roles in airway obstruction. Nevertheless, airway smooth muscle contraction is important and is the main target of emergency bronchodilator treatment. In addition, not all of the subjects in these studies were taking inhaled corticosteroids, whereas current guidelines recommend that long-acting beta-agonists are used in conjunction with inhaled corticosteroids $[1,2]$. There is conflicting evidence on whether systemic corticosteroids may partly reverse tolerance [32]. However, it is known that stable doses of inhaled corticosteroids do not influence the development of tolerance [5] and hence the use of inhaled corticosteroids was not a requirement in our selection of subjects.

This study is the first to demonstrate that beta-agonist bronchodilator tolerance can be demonstrated using hypertonic saline. Most previous studies using the 'challenge-rescue' technique have used methacholine as the challenge agent [5-8,10-12,33]. This would have been inappropriate prior to studying the response to the anticholinergic drug ipratropium. Our findings confirm that the challenge-rescue model for studying bronchodilator tolerance works with both direct and indirect challenges. The bronchial response to hypertonic saline challenge is closely correlated with the response to exercise challenge [34]. A suboptimal response to salbutamol after exercise challenge has also been found when patients use regular beta-agonists [9].

\section{Conclusion}

In summary, these studies confirm that beta-agonist bronchodilator tolerance develops during long-acting betaagonist treatment. This is not overcome by $5 \mathrm{mg}$ of nebulised salbutamol. The effect is specific to beta-agonists and does not affect the response to ipratropium bromide. Patients using long-acting beta-agonists may respond less well to emergency beta-agonist treatment. Additional treatment with an alternative bronchodilator should be considered early in the course of an exacerbation.

\section{Abbreviations}

AMP - adenosine 5'monophosphate

AUC - area under the curve

$\mathrm{FEV}_{1}$ - forced expiratory volume in one second

$\mathrm{PD}_{20}$ - dose of bronchoprovocational challenge agent required to produce a fall in $\mathrm{FEV}_{1}$ of $20 \%$ from baseline

\section{Competing interests}

The author(s) declare that they have no competing interests.

\section{Authors' contributions}

SH contributed to the trial design, acquired the data, performed the statistical analysis and helped to draft the manuscript. RH conceived the study, participated in its design, interpretation of results and helped to draft the manuscript.

\section{Acknowledgements}

We would like to thank the study participants. We also thank Dr J McLachlan and the staff of the Waikato Hospital Respiratory Laboratory, Dr Graham Mills and the Waikato Respiratory Research Unit and Jan Cowan of the Respiratory Research Unit in the Dunedin School of Medicine. The study was funded by the Waikato Respiratory Research Fund.

\section{References}

I. Global strategy for asthma management and prevention. Edited by: Institute NIHNHLB. Bethesda ; 2002:NIH publication no 96-3659A. updated 2005

2. BTS: British guideline on the management of asthma. Thorax 2003, 58(suppl I): I-83.

3. Newnham DM, Grove A, McDevitt DG, Lipworth BJ: Subsensitivity of bronchodilator and systemic $\beta 2$ adrenergic responses after regular twice daily treatment with eformeterol dry powder in asthmatic patients. Thorax 1995, 50:497-504.

4. Cheung D, Timmers MC, Zwinderman AH, GBel EH, Dijkman JH, Sterk PJ: Long-term effects of a long-acting $\beta 2$-adrenocepter agonist, salmeterol, on airway hyperresponsiveness in patients with mild asthma. N Engl J Med 1992, 327: I I 98-1 203.

5. Hancox RJ, Aldridge RE, Cowan JO, Flannery EM, Herbison GP, McLachlan CR, Town GI, Taylor DR: Tolerance to beta agonists during acute bronchoconstriction. Eur Respir J 1999, 14:283-287.

6. Jones SL, Cowan JO, Flannery EM, Hancox RJ, Herbison GP, Taylor DR: Reversing acute bronchoconstriction in asthma: the effect of bronchodilator tolerance. Eur Respir J 200I, I 7:368-373.

7. Wraight JM, Hancox RJ, Herbison GP, Cowan JO, Flannery EM, Taylor DR: Bronchodilator tolerance: the impact of increasing bronchoconstriction. Eur Respir J 2003, 21:810-815.

8. Van der Woude HJ, Winter TH, Aalbers R: Decreased bronchodilating effect of salbutamol in relieving methacholine induced moderate to severe bronchoconstriction during high dose treatment with long acting $\beta 2$ agonists. Thorax 200I, 56:529-535.

9. Storms WW, Chervinsky P, Ghannam A, Bird S, Hustad CM, Edelman JM: A comparison of the effects of oral montelukast and inhaled salmeterol on response to resuce bronchodilation after challenge. Respir Med 2004, 98:105I-1062.

10. Lee DKC, Jackson CM, Currie GP, Cockburn WJ, Lipworth BJ: Comparison of combination inhalers vs inhaled corticosteroids alone in moderate persistent asthma. Br J Clin Pharmacol 2003, 56:494-500. 
II. Haney S, Hancox RJ: Rapid onset of tolerance to beta-agonist bronchodilation. Respir Med 2005, 99:566-57I.

12. Haney S, Hancox RJ: Tolerance to bronchodilation during treatment with long-acting beta-agonists, a randomised controlled trial. Respiratory Research 2005, 6:107.

13. Haney S, Hancox RJ: Recovery from bronchoconstriction and bronchodilator tolerance. Clin Rev Allergy Immunol 2006, 3I:18I-196.

14. Sears MR, Lotvall J: Past, present and future - $\beta 2$-adrenoceptor agonists in asthma management. Respir Med 2005, 99:152-170.

15. Rodrigo G, Rodrigo C: The role of anticholinergics in acute asthma treatment. Chest 2002, I 21:1977-1987.

16. Giembycz MA, Newton R: Beyond the dogma: novel $\beta 2$-adrenoceptor signalling in the airways. Eur Respir J 2006, 27(6): $1286-1306$

17. Sarria B, Naline E, Zhang Y, Cortijo J, Molimard M, Moreau J, Therond $\mathrm{P}$, Advernier C, Morcillo Ej: Muscarinic M2 receptors in acetylcholine-isoproterenol functional antagonism in human isolated bronchus. American Journal of Lung Cell Molecular Physiology 2002, 283:LII 25-LII 32.

18. Cockcroft DW, O'Byrne PM, Swystun VA, Bhagat R: Regular use of inhaled albuterol and the allergen-induced late asthmatic response. J Allergy Clin Immunol 1995, 96:44-49.

19. Hancox RJ, Subbarao P, Kamada D, Watson R, Hargreave FE, Inman MD: Beta 2 agonist tolerance and exercise-induced bronchospasm. Am J Respir Crit Care Med 2002, 165:1068-1070.

20. Yan K, Salome C, Woolcock AJ: Rapid method for measurement of bronchial responsiveness. Thorax 1983, 38:760-765.

21. Sterk PJ, Fabbri LM, Quanjer PH, Cockcroft DW, O'Byrne PM, Anderson SD, Juniper EF, Malo JL: Airway responsiveness. Standardized challenge testing with pharmacological, physical and sensitizing stimuli in adults. Eur Respir J 1993, 6:53-83.

22. Colacone A, Afilalo M, Wolkove N, Kreisman H: A comparison of albuterol administered by metered dose inhaler (and holding chamber) or wet nebulizer in acute asthma. Chest 1993, 104:835-84I.

23. Rodrigo G], Rodrigo C: First-line therapy for adult patients with acute asthma receiving a multiple-dose protocol of ipratropium bromide plus albuterol in the emergency department. Am J Respir Crit Care Med 2000, I6 I(6): |862-1868.

24. Korosec M, Novak RD, Myers E, Skowronski M, McFadden ER: Salmeterol does not compromise the bronchodilator response to albuterol during acute episodes of asthma. Am J Med 1999, 107:209-213.

25. Windom HH, Burgess CD, Crane J, Pearce N, Kwong T, Beasley R: The self-administration of inhaled beta agonist drugs during severe asthma. N Z Med J 1990, 103:205-207.

26. Gosens R, Zaagsma J, Meurs H, Halayko AJ: Muscarinic receptor signalling in the pathophysiology of asthma and COPD. Respiratory Research 2006, 7:73.

27. Watson N, Magnussen H, Rabe KF: Antagonism of $\beta$-adrenoceptor-mediated relaxations of human bronchial smooth muscle by carbachol. Eur J Pharmacol 1995, 275:307-310.

28. Barnes PJ: Beta-adrenergic receptors and their regulation. Am J Respir Crit Care Med 1995, I 52:838-860.

29. Ullah MI, Newman GB, Saunders KB: Influence of age on response to ipratropium and salbutamol in asthma. Thorax 1981, 36:523-529.

30. Dollery C: Therapeutic Drugs: formoterol. In Therapeutic Drugs 2nd edition. Edited by: Dollery C. Churchill Livingstone; 1999:FI55-FI58.

31. Brodde OE, Daul A, Michel-Reher M, Boosma F, Man in't Veld AJ, Schlieper P, Michel MC: Agonist-induced desensitization of $\beta$ adrenoceptor function in humans. Circulation 1990, 81:9|4-921.

32. Hancox RJ: Interactions between corticosteroids and $\beta 2$-agonists. Clin Rev Allergy Immunol 2006, 3 I:23 I-246.

33. Lee DKC, Jackson CM, Bates CE, Lipworth BJ: Cross tolerance to salbutamol occurs independently of $\beta 2$ adrenoceptor genotype-16 in asthmatic patients receiving regular formoterol or salmeterol. Thorax 2004, 59:662-667.

34. Makker HK, Holgate ST: Relation of the hypertonic saline responsiveness of the airways to exercise induced asthma symptom severity and to histamine or methacholine reactivity. Thorax 1993, 48: 142-147.
Publish with Biomed Central and every scientist can read your work free of charge

"BioMed Central will be the most significant development for disseminating the results of biomedical research in our lifetime. "

Sir Paul Nurse, Cancer Research UK

Your research papers will be:

- available free of charge to the entire biomedical community

- peer reviewed and published immediately upon acceptance

- cited in PubMed and archived on PubMed Central

- yours - you keep the copyright

Submit your manuscript here:

http://www.biomedcentral.com/info/publishing_adv.asp
BiolMedcentral 